\title{
Equity and Entitlement: Internal Barriers to Improving the Pay of Academic Librarians
}

\section{Janice J. Kirkland}

\begin{abstract}
Academic librarians, because of their education and abilities, deserve higher salaries, yet the disparity between the high requirements and low pay in the profession has not led to widespread pay equity campaigns. Research studies suggest a link beween the female majority in librarianship and women's lower sense of entitlement, leading to acceptance of the status quo. Librarians substitute methods such as cognitive reevaluation and circumscribed comparisons for realistic confrontation with inequities. Instead, they should eliminate defensive barriers and work cooperatively for the rewards to which they are entitled.
\end{abstract}

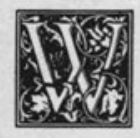

hat group of new professionals is expected to have two or more degrees from approved institutions of higher education, mastery of foreign languages, knowledge of national standards, understanding of the latest technological developments, and ability in practical applications in the major subfields of their profession? According to some job advertisements, entrylevel librarians must meet the above criteria, as well as demonstrate ability to work with people, skill in oral and written communication, and activity in professional organizations. For tenure-track academic librarians, further promotional requirements are added: teaching expertise, publication, campus service, committee membership in professional organizations, and perhaps continuing education. The requirements differ among institutions, but in all institutions they become more demanding as a librarian progresses beyond entry level.

It would be reasonable to expect that the pay in a profession that expects so much would be commensurate with the requirements, but this is definitely not the case. Only a few states have adopted minimum salaries as recommended by the American Library Association. Salaries in Association of Research Libraries member libraries in 1989 started at $\$ 18,500$, a salary lower than the pay in many male-dominated fields requiring only high school or trade school preparation. ${ }^{1}$ Groundsworker, parking attendant, and equipment technician are examples.

The disparity between librarians' increasingly demanding performance and their comparatively low monetary compensation is startling. However, this disparity is more often met with acceptance than with analysis leading to action. In this article, the author, observing that librarianship is composed mainly of women, proposes a new basis for analysis and action toward pay equity by applying to librarianship the findings of recent psychological and management studies. ${ }^{2}$

Some theorists studying pay equity have come to the conclusion that a major

Janice J. Kirkland is Bibliographic Control Coordinator at California State University, Bakersfield, Bakersfield, California 93311. 
disparity between the relative pay and the relative social prestige of an occupation may lead to feelings of deprivation and unrest. ${ }^{3}$ Clearly, such a disparity exists in librarianship, yet there does not seem to be universal unrest. Perhaps in spite of the demanding nature of its responsibilities, the profession's perceived status may not be high enough to bring about pay-prestige unrest. A second study suggests that academics, including librarians, generally are little affected by perceptions of pay equity and recommends further research on the question. $^{4}$

\section{The disparity between librarians' in- creasingly demanding performance and their comparatively low mone- tary compensation is startling.}

However, another possible reason exists for the lack of agitation over universal pay inequity among academic librarians, many of whom deal with low salaries by not dealing with them. Academic librarians may be using techniques that eliminate the need to protest. Two such techniques are cognitive reevaluation and circumscribing the field for comparisons. What underlying cause could have made it necessary to adopt such coping attitudes? Because the majority of academic librarians are women, and because the men in the minority are socialized to a degree by the female majority, it is likely that women's self-image is a cause for such attitudes, particularly with respect to esteem and entitlement. Research supports this contention.

\section{COGNITIVE REEVALUATION}

When a perceived pay inequity arouses dissatisfaction, workers do not always act directly to address and remove the inequity. Instead, they may substitute a cognitive response for a behavioral response and receive satisfaction entirely unrelated to redressing the inequity. They may do this when the inequity is not removable or when it is perceived as being unremovable. From the worker's viewpoint, these are the same. Cognitive redefinition of the situation is a low-risk solution that is not costly in time or energy and that does not threaten job security. ${ }^{5}$ Monetary reward is only one of the satisfactions of employment. If pay is not satisfactory, workers may augment cognitively the reward value of other aspects of the job, such as its physical environment ("the building is new and close to everything"), its contacts with colleagues ("this is such a friendly staff"), its social service value ("I became a librarian in order to help others"), or its intellectual fringe benefits ("the job gives me access to material for my own research"). Such reevaluation would not be harmful, except that it substitutes for and even prevents positive steps to rectify the pay inequity.

\section{CIRCUMSCRIBING THE FIELD FOR COMPARISON}

A curious observer perusing Library Literature for the past five years for evidence of active and visible pay equity campaigns in academic libraries would find limited information. The major headings of "Classification and pay plans," "Job analysis," and "Salaries" identify only a handful of articles dealing with institutions in a few of the fifty states. The observer would have to agree with Brent S. Steel and Nicholas P. Lovrich, Jr., who identified a similar lack of activity among public employees in general:

Given the objective evidence of a wage gap, and the active pursuit of the comparable worth principle in the courts and in federal and state legislative bodies, logic would seem to dictate that rational, self-interested women must manifest attitudes reflecting a desire to end inequitable compensation treatment. No such evidence is to be found, however. Quite to the contrary, there appears to be some evidence that women public servants are more satisfied with their lot than are their male counterparts! ${ }^{6}$

Steel and Lovrich conclude that decades of assertiveness training will be required to counteract "norms of social resignation and compliance with au- 
thority (even unjust authority)," which prevail in employment fields where women are in the majority. These norms have retained their efficacy because they are reinforced by frequent calls for public employees to give sacrificial service and devotion to duty in the public interest. Substitute for "public interest" the phrase "in the interest of the college or university and the students" and the description is also applicable to academic librarians. Because as the majority of the workers are women, they are already predisposed toward self-sacrifice by the traditional expectations of society at large. What is not often noticed, however, is the fact that the instructional faculty members, who are composed of two-thirds to three-quarters men, are not impeded in their dedication to the university and the students by receiving considerably higher rates of pay than librarians.

The satisfaction with lower pay that women often display may also be partially attributed to their selection of other groups with which to compare their salaries. Generally, women seem more likely to compare their pay with that of other women, and men to compare their pay with that of other men. Thus women academic librarians, finding themselves equal to or better paid than other women (academic librarians are better paid than public librarians, and public librarians are better paid than clerical workers or secretaries) have more tolerance for underpayment than men. If librarians, instead of using as their standard the salaries in depressed fields where women predominate, compared their salaries with salaries in male-dominated academic fields where the master's degree is also the terminal degree - such as arts, athletics, and technical areas-their views might change. Circumscribed comparisons work against consciousness of pay inequities (the author will return to this point).

\section{ENTITLEMENT AND EQUITY}

Pamela K. Adelmann's investigation of the relationship between occupational characteristics, such as complexity and control and aspects of psychological well-being, found that higher income was associated with lower vulnerability and, thus, with greater feelings of wellbeing. However, higher income was more closely associated with happiness for men than it was for women. ${ }^{8}$ Because those in "women's" professions have usually found it difficult to achieve higher income, this result is not particularly startling. Adelmann suggests that women may look for happiness in other roles, but does not indicate that they may do so because they have to. Women would be foolish to link happiness to high incomes they may never earn. Other research indicates that women do not feel as entitled to higher income as do men.

The concept of entitlement is closely linked with self-esteem. The idea that levels of self-esteem are affected by an individual's sense of entitlement is increasingly recognized as a vital factor in many areas, including the education of minorities as well as the employment of women. Management literature in librarianship recognizes that librarians belong to different races, but often seems to assume that they have no gender. Fortunately, this literature is beginning to give more extensive coverage to the important issues of esteem and entitlement. A recent example is Rosie L. Albritton and Thomas W. Shaughnessy's Developing Leadership Skills: A Source Book for Librarians, which contains a section on women that discusses internal barriers, self-esteem, and self-concept.9

An individual's high or low sense of entitlement may have some interesting effects on their actions. Brenda Major, Dan B. McFarlin, and Diana Gagnon conducted experiments in which men and women were allowed to set their own fair pay for performing identical tasks for a specified length of time. The men consistently paid themselves more. ${ }^{10}$ From a total of $\$ 4$ each, the subjects were asked to pay themselves what they considered fair for their work; no comparisons of what others had been paid were given. The women took an average of $\$ 1.95$ for their work, and the men took $\$ 3.18$. This difference in pay was appar- 
ently unrelated to the fact that both the women and the men thought that their performances were good.

Another experiment by Brenda Major verified the hypothesis that because women have less sense of personal entitlement, they will work longer and work more for a set amount of pay than will men. The subjects were given $\$ 4$ and were told to perform a somewhat boring task long enough to earn that amount. "As predicted, women worked significantly longer, did more work, completed more correct work, and worked more efficiently than men, both when they thought their work was monitored and when they thought it was unmonitored." 11

Expanding on these earlier findings, Major's later experiments took the process two steps further by having women and men select others with whom to compare their pay, and then rate their own satisfaction with what they had paid themselves. The women subjects compared themselves with other lowly paid women and rated themselves as satisfied with their low pay. ${ }^{12}$ Such a downward comparison strategy enables subjects to increase or maintain their feelings of well-being by avoiding unpleasant comparisons with those who are better paid. Thus, the use of circumscribed fields of comparison becomes an established method of psychological self-defense, which is consistent with women's feelings of low entitlement.

In applying these findings to librarianship, it is not necessary to assume that all women librarians suffer from feelings of low entitlement. Clearly, this is not the case because recent pay equity movements exist in various academic libraries and library systems and because the ALA pay equity committee is pursuing a variety of strategies to improve salaries. However, it seems likely that many women academic librarians' feelings of low entitlement have played a role in limiting the extent of pay equity movements.

The fact that some people do not internalize societal gender roles and others internalize them only to a limited extent does not... provide a basis for predicting that behavioral sex differences are typically minimal. It should be kept in mind that group averages representing the social attitudes and self-concepts of women and men do differ along gender-stereotypic lines. ${ }^{13}$

\section{The question naturally arises as to why male librarians, who should have a higher sense of entitlement, are not leading pay equity campaigns in all libraries.}

For pay equity purposes, recognizing the likelihood that librarians as a group are influenced by lessened consciousness of entitlement is the necessary first step toward correcting the lack of self-esteem.

Because not all librarians are women, the question naturally arises as to why male librarians, who should have a higher sense of entitlement, are not leading pay equity campaigns in all libraries. Many men are indeed active in trying to improve salaries but, because it is statistically more likely that men will reach the higher salaries found in library administration, some of them may not feel permanently confined to the lower salaries of the rank and file and, therefore, may have less impetus to correct the situation. Another possible reason for male inactivity might be called contagious or derivative low entitlement. It is not women alone, but those in "women's" professions, regardless of their gender, who may demonstrate a lower sense of entitlement. Labeling a field "feminine" may lower its perceived worth and, thus, affect the perceived personal entitlement of anyone working in the field; male librarians' negative self-perceptions probably indicate a low sense of entitlement. ${ }^{14}$

\section{CONCLUSION}

The body of social and psychological research indicates that personal behavior relating to what people earn and what people feel they should earn is ex- 
tremely complex and can include defensive barriers erected by the low-paid against the recognition that they receive unfair social treatment. To remove or alter these barriers that enable librarians not only to work for less than they are worth, but to express satisfaction at the inequitable situation, could undoubtedly not be done without causing some psychological distress. This distress could be minimized by elevating librarians' selfesteem and consciousness of entitlement through methods that are being developed in fields such as educational psychology. Concerned library administrators and library organizations should consider in- cluding entitlement components in staff training, workshops, and conference programs. ${ }^{15}$

The discomfort of losing the internal barriers that keep academic librarians from acknowledging pay inequity would be temporary, and strong reasons exist for leveling the barriers. They would be replaced by the growth of skills and abilities necessary to mount pay equity campaigns, by "more respect and recognition for the value of library work," and by satisfaction at moving together toward the equitable higher salaries to which academic librarians are truly entitled. ${ }^{16}$

\section{REFERENCES}

1. Janice J. Kirkland, "Personnel and Employment: Compensation and Pay Equity," in ALA Yearbook for Library and Information Services 1990 (Chicago: American Library Assn., 1990), p.189.

2. The following 1986 ALA statistics are rounded to the nearest percent: academic libraries: $66 \%$ women, $34 \%$ men; public libraries: $80 \%$ women, $20 \%$ men; all libraries: $75 \%$ women, $25 \%$ men. ALA Office for Library Personnel Resources, Academic and Public Librarians: Data by Race, Ethnicity and Sex (Chicago: American Library Assn., 1986), table II. Information from library schools in 1988 indicated that the overall percentages are unlikely to change and that acceptance of low pay begins early. See William Moen and Kathleen Heim, Librarians for the New Millennium (Chicago: American Library Assn./Off. for Library Personnel Resources, 1988) p.96, 106. The 3,455 library school students surveyed were $19.1 \%$ male and $80.9 \%$ female. The students expected to receive low starting salaries, yet more than half expressed "contentment with the amount."

3. Miriam Dornstein, "Pay Equity Evaluations of Occupations and Their Bases," Journal of Applied Social Psychology 18:905-24 (Aug. 1988).

4. Christopher Orpen and Josef Bonnici, "Effect of Perceptions of Pay Equity on Employees' Motivation, Involvement, Satisfaction, and Performance," Perceptual and Motor Skills 65:601-02 (Oct. 1987).

5. Jerald Greenberg, "Cognitive Reevaluation of Outcomes in Response to Underpayment Inequity," Academy of Management Journal 32:174-83 (Mar. 1989).

6. Brent S. Steel and Nicholas P. Lovrich, Jr., "Comparable Worth: The Problematic Politicization of a Public Personnel Issue," Public Personnel Management 16:23-36 (Spring 1987).

7. Timothy P. Summers, "Examination of Sex Differences in Expectations of Pay and Perceptions of Equity in Pay," Psychological Reports 62:491-96 (Apr. 1988).

8. Pamela K. Adelmann, "Occupational Complexity, Control, and Personal Income: Their Relation to Psychological Well-being in Men and Women," Journal of Applied Psychology 72:529-37 (Nov. 1987).

9. Rosie L. Albritton and Thomas W. Shaughnessy, Developing Leadership Skills: A Source Book for Librarians (Englewood, Colo.: Libraries Unlimited, 1990), p.43-86.

10. Brenda Major, Dan B. McFarlin, and Diana Gagnon, "Overworked and Underpaid: On the Nature of Gender Differences in Personal Entitlement," Journal of Personality and Social Psychology 47:1399-1412 (Dec. 1984).

11. Brenda Major, "Women and Entitlement," Women and Therapy 6:3-19 (Fall 1987). See also Brenda Major and Ellen Konar, "An Investigation of Sex Differences in Pay Expectations and Their Possible Causes," Academy of Management Journal 27:777-92 (Dec. 1987). 
12. Brenda Major and Maria Testa, "Social Comparison Processes and Judgments of Entitlement and Satisfaction," Journal of Experimental Social Psychology 25:101-20 (Mar. 1989).

13. Alice H. Eagly, Sex Differences in Social Behavior: A Social-Role Interpretation (Hillsdale, N.J.: Erlbaum, 1987), p.19.

14. Locke J. Morrissey and Donald O. Case, "There Goes My Image: The Perception of Male Librarians by Colleague, Student and Self," College \& Research Libraries 49:453-64 (Sept. 1988). The study concludes that male librarians view themselves more negatively than other respondents view them.

15. Databases such as ERIC and Psyclit contain numerous sources on self-esteem and self-concept. Underpaid library paraprofessionals could also benefit from such training; many feel underconsulted about their increasingly demanding responsibilities, a possible source for feelings of low entitlement. See Dorothy Jones, "Library Support Staff and Technology: Perceptions and Opinions," Library Trends 37:432-56 (Spring 1989).

16. Carolyn Kenady, Pay Equity: An Action Manual for Library Workers (Chicago: American Library Assn., 1989), p.54.

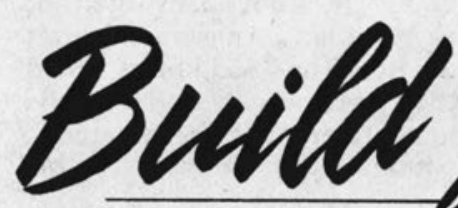

For More Information:

50 East Huron Street

Chicago, IL 60611-2795

Toll Free 1-800-545-2433

Ext. 2516

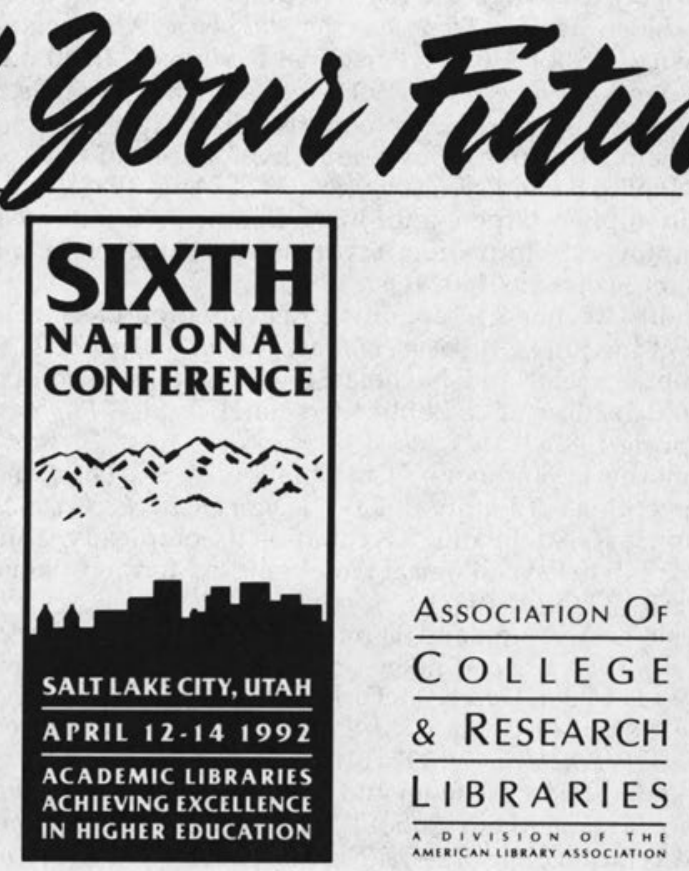

